\title{
Rediscovery of Tetraëdriella subglobosa PAscher, a member of the Eustigmatophyceae
}

\author{
Marvin W. FAWLEY ${ }^{1 *} \&$ Karen P. FAWLEY ${ }^{1}$ \\ ${ }^{1}$ School of Mathematical and Natural Sciences, University of Arkansas at Monticello, Monticello, Arkansas, \\ 71656, USA; "Corresponding author e-mail: fawleym@uamont.edu
}

\begin{abstract}
An algal strain from an acidic pool near the shore of Lake Mácha, Czech Republic, was identified as Tetraëdriella subglobosa Pascher by light microscopy. Phylogenetic analysis of nuclear 18S rDNA and plastid $r b c \mathrm{~L}$ sequence data indicated that this alga is a member of the Eustigmatophyceae, rather than the Xanthophyceae as presently classified. This is the first report of $T$. subglobosa since Pascher's description of the species in 1930 .
\end{abstract}

Key words: Eustigmatophyceae, Goniochloridales, phylogeny, rbcL, Tetraëdriella, 18S rDNA

\section{INTRODUCTION}

One of the many heterokont algae that were described by Pascher in the early $20^{\text {th }}$ century is Tetraëdriella subglobosa, which Pascher found in acidic pools near Františkovy Láznê and Lake Mácha, Czech Republic (PASCHER 1930). To our knowledge, there are no other records for this species. Tetraëdriella subglobosa is listed in a database of Czech algae (PouLí̌́KovÁ et al. 2004), but with no data except the original description. AlgaeBase (Guiry \& Guiry 2015) does not list T. subglobosa under the genus Tetraëdriella, despite the fact that it was one of the two original species in the genus (PAscher 1930).

Tetraëdriella subglobosa is a small $(8-13 \mu \mathrm{m})$, nearly spherical organism with a finely sculpted cell wall. However, some of the cells display a slight pyramidal or tetrahedral shape, with the walls highly convex so as to be nearly spherical. The cell walls have thickened bands that form the edges of the tetrahedron. The edges are easily seen in the old mother cell walls that result from autospore formation. The small size and simple morphology of T. subglobosa make it likely that this species has been overlooked or identified as other similar taxa, such as some species of Trachydiscus Ettl or even Pleurochloris Pascher.

We collected water samples from acidic pools at the Lake Mácha site in April, 2014 and cultured several Eustigmatophyceae strains from these samples. We have identified one of these strains as Tetraëdriella subglobosa. Here we present the results of phylogene- tic analysis of nuclear $18 \mathrm{~S}$ rDNA and plastid $r b c \mathrm{~L}$ sequence data for this organism, as well as new insights on its morphology.

\section{Materials ANd Methods}

Strain isolation. A tychoplankton sample was collected from an acidic pool near the shore of Lake Mácha, Czech Republic, (approximately $50.577^{\circ} \mathrm{N}, 14.699^{\circ} \mathrm{E}$ ) on 24 April, 2014. The sample was kept chilled and transported to our laboratory in Monticello, Arkansas, USA, and processed on 2 May, 2014. Tetraëdriella subglobosa was isolated from a sample spread on an agar plate of M5.5 medium and incubated at room temperature under continuous cool-white fluorescent light. The M5.5 medium is made by diluting $\mathrm{WH}+$ medium (FAwLEY et al. 2013) 1:9 with distilled water, adding 0.1 g. $1^{-1}$ MES buffer (Fisher Scientific BP300, Thermo Fisher Scientific, Hampton, New Hampshire, USA) and adjusting the $\mathrm{pH}$ to 5.5 with sodium hydroxide. Tetraëdriella subglobosa strain F4 4/24-10m was maintained on M5.5 agar. This strain is now also held by the Culture Collection of Algae at Charles University in Prague as CAUP Q 601.

Light Microscopy. A Nikon NiU microscope (Nikon, Melville, New York, USA) equipped with a Plan Apochromat 100x objective (numerical aperture 1.45) and differential interference contrast optics was used for light microscopy. Images were captured with a Nikon DS-Fi2 digital camera and Nikon Elements BR software. Strain F4 4/24-10m was grown in M5.5 liquid medium at $20^{\circ} \mathrm{C}$ with illumination of about $50 \mu \mathrm{M} \cdot \mathrm{m}^{-2} \cdot \mathrm{sec}^{-1}$ and a 12:12 light:dark cycle and examined within 10 days of inoculation. Three different techniques were used to stimulate zoospore production. An 
exponentially growing culture in liquid medium was placed in darkness (wrapped in aluminum foil) for at least $18 \mathrm{~h}$ at either $20^{\circ} \mathrm{C}$ (LeE \& Bold 1973) or at $10{ }^{\circ} \mathrm{C}$ (TrzcińsKA et al. 2014), or fresh liquid medium was applied to the surface of a culture on agar medium that was over 1 month old which was then placed in darkness for at least 5 days (SANTOS \& LEEDALE 1991).

Phylogenetic analysis. Strain F4 4/24-10m was grown in liquid M5.5 medium as above. Cells were collected by centrifugation and DNA was isolated according to FAWLEY \& FAWLEY (2004). Previously collected genomic DNA samples from other Eustigmatophyceae strains were also used to generate new $r b c \mathrm{~L}$ sequences to complete a data set for that locus similar to the taxon set used in FAwLEY et al. (2014). Conditions for polymerase chain reaction amplification were as described in FAWLEY \& FAWLEY (2004) for the nuclear 18S rDNA region and FAWLEY et al. (2015) or PRIOR et al. (2009) for the plastid $r b c \mathrm{~L}$ gene. DNA sequencing was performed as described in FAWLEY et al. (2015), with sequencing done by Sequetech (Mountain View, California, USA). Sequence reads were joined using the Staden Package 2.0.0b8. New 18S rDNA sequences from F4 4/24-10m (KX373531) and additional new sequences published in GenBank (Table 1) were added to the alignment of FAWLEY et al. (2014) and aligned by eye in MacClade 4.08 (MADDISON \& MADDISON 2000). A concatenated $18 \mathrm{~S}$ rDNA and $r b c \mathrm{~L}$ alignment including the new $r b c \mathrm{~L}$ sequences for $T$. subglobosa (KX354388) and additional strains (Table 1) was produced in MacClade 4.08. Taxa lacking $r b c \mathrm{~L}$ sequences were excluded from the concatenated alignment except for Vacuoliviride crystalliferum, Trachydiscus sp. LCR-AWA-9-2, strain Itas 9/21 S$-11 \mathrm{w}$, Pseudostaurastrum enorme and Pseudostaurastrum limneticum, all members of the clade Goniochloridales.

Maximum Parsimony (MP) analyses were performed with PAUP* 2.0b (SwOFFord 2002) and Maximum Likelihood (ML) analyses employed GARLI 2.01 (ZwICKL 2006), under the GTR $+\mathrm{I}+\Gamma$ model of substitution (TAVARÉ 1986) with parameters selected by GARLI. The ML analysis of the concatenated data set had partitions for $18 \mathrm{~S}$ rDNA and each codon position of the $r b c \mathrm{~L}$ sequences. Twenty replicates with different starting trees were used for ML analyses. Maximum Parsimony analyses were bootstrapped with 1000 replicates of the data and ML analyses were bootstrapped with 200 replicates, with each replicate evaluated for 2 random starting trees.

Outgroup taxa for phylogenetic analyses with GenBank accession numbers for $18 \mathrm{~S}$ rDNA and $r b c \mathrm{~L}$ were Aurearena cruciata (AB365192, AB365193), Botrydium stoloniferum (U41648, AFR064743), Chromulina nebulosa (AF123285, AF155876), Pylaiella littoralis (AY032606, X55372) and Synchroma grande (DQ788730, DQ788731). The concatenated alignment included the following taxa from the Eustigmatales for which both $18 \mathrm{~S}$ rDNA and $r b c \mathrm{~L}$ sequences are available: strain BogD 9/21 T-2d (KF757230, GQ405004); Eustigmatos magnus CCMP 387 (U41051, AF015575); strain Mary 6/3 T-1w (KF757240, GQ405005); strain Mary 8/18 T-3d (KF757238, KX354375); strain Mary 8/18 T-4d (KF757239, KX354376); Monodus unipapilla SAG 8.83 (AM490827, HQ710608); Microchloropsis gaditana MBIC10123 (AM052270, AB052734); Microchloropsis salina CCAP 840/2 (AF045046, AB052288); Nannochloropsis granulata CCMP1662 (AF045041, AB052280); Nannochloropsis limnetica SAG 18.99 (AF251496, AF251496); Nannochloropsis oceanica MBIC10090 (AB183587,
AB052283); Nannochloropsis oculata CCMP525 (U38902, HQ710609); strain Tow 8/18 T-6d (KF757249, KX354384); strain Tow 8/18 T-12d (KF757250, KX354385), strain Tow 9/21 P-2w (KF757253, KX354386) and strain WTwin 8/18 T-5d (KF757254, GQ405007).

For the figures resulting from all analyses, the generic name Monodus was used with the GenBank accessions of Monodus and Monodopsis because the taxonomy of Monodus and Monodopsis is quite confused and uncertain (Отт et al. 2015).

\section{Results AND Discussion}

Light microscopy indicated the presence of a prominent orange lipid body in the cytoplasm of strain F4 4/24-10m, along with a finely sculpted cell wall (Figs

Table 1. GenBank accession numbers of new and updated DNA sequences of Eustigmatophyceae used in this study. All unnamed strains are from Itasca State Park (ISP) in Minnesota, USA, except Chic 10/23 P-6w and Chic 10/23 P-37w from Lake Chicot, Arkansas, USA. See FAwLEY et al. (2004) for descriptions of sites in ISP and FAWLEY et al. (2013) for a description of Lake Chicot.

\begin{tabular}{|c|c|}
\hline Eustigmatophyceae strain & $\begin{array}{l}\text { Locus and GenBank } \\
\text { accession number }\end{array}$ \\
\hline Chic 10/23 P-6w & $r b c \mathrm{~L} \mathrm{KX354371}$ \\
\hline Chic $10 / 23 \mathrm{P}-37 \mathrm{w}$ & $r b c \mathrm{~L} \mathrm{KX354372}$ \\
\hline Itas $6 / 3 \mathrm{~T}-8 \mathrm{w}$ & $r b c \mathrm{~L} \mathrm{KX354373}$ \\
\hline Itas $8 / 18 \mathrm{~S}-5 \mathrm{~d}$ & $r b c \mathrm{~L} \mathrm{KX354374}$ \\
\hline Itas $9 / 21 \mathrm{~S}-8 \mathrm{~W}$ & $r b c \mathrm{~L}$ GQ405009 update \\
\hline Mary $8 / 18 \mathrm{~T}-3 \mathrm{~d}$ & $r b c \mathrm{~L} \mathrm{KX354375}$ \\
\hline Mary $8 / 18 \mathrm{~T}-4 \mathrm{~d}$ & $r b c \mathrm{~L} \mathrm{KX354376}$ \\
\hline Mary 8/18 T-4w & $r b c \mathrm{~L} \mathrm{KX354377}$ \\
\hline Pic 8/18 P-2d & $r b c \mathrm{~L} \mathrm{KX354378}$ \\
\hline Pic $8 / 18 \mathrm{P}-13 \mathrm{~d}$ & $r b c \mathrm{~L} \mathrm{KX} 354379$ \\
\hline Pic $8 / 18 \mathrm{~T}-15 \mathrm{~d}$ & $r b c \mathrm{~L} \mathrm{KX} 354380$ \\
\hline Pic $8 / 18 \mathrm{~T}-19 \mathrm{w}$ & $r b c \mathrm{~L} \mathrm{KX354381}$ \\
\hline Tow $2 / 24 \mathrm{P}-2 \mathrm{~d}$ & $r b c \mathrm{~L} \mathrm{KX354382}$ \\
\hline Tow $8 / 18 \mathrm{~T}-2 \mathrm{~d}$ & $r b c \mathrm{~L} \mathrm{KX354383}$ \\
\hline Tow $8 / 18 \mathrm{~T}-6 \mathrm{~d}$ & $r b c \mathrm{~L} \mathrm{KX} 354384$ \\
\hline Tow $8 / 18 \mathrm{~T}-12 \mathrm{~d}$ & $r b c \mathrm{~L} \mathrm{KX} 354385$ \\
\hline Tow 8/18 T-4w & $r b c \mathrm{~L}$ GQ405008 update \\
\hline Tow 8/18 T-8w & $r b c \mathrm{~L} \mathrm{GO} 405010$ update \\
\hline Tow $9 / 21 \mathrm{P}-2 \mathrm{w}$ & $r b c \mathrm{~L} \mathrm{KX} 354386$ \\
\hline WTwin $8 / 18 \mathrm{~T}-15 \mathrm{~d}$ & $r b c \mathrm{~L} \mathrm{KX} 354387$ \\
\hline T. subglobosa F4 4/24-10m & $r b c \mathrm{~L} \mathrm{KX} 354388$ \\
\hline T. subglobosa $\mathrm{F} 4$ 4/24-10m & 18S rDNA KX373531 \\
\hline
\end{tabular}


1-8). These features are indicative of some clades in the Eustigmatophyceae (FAWLEY et al. 2014). The cells ranged from about $3.0 \mu \mathrm{m}$ for autospores to $10.0 \mu \mathrm{m}$ for large vegetative cells. Occasional giant cells $20 \mu \mathrm{m}$ or larger were found, especially in older cultures (not shown). Cells often appeared spherical, but careful observation revealed that they are typically somewhat irregular, oblong or roughly elliptical. Ridges on the cell walls were sometimes visible, but were best seen on old mother cell walls that had released autospores. One to four (or more in giant cells, not shown) plastids formed smooth parietal sheets without pyrenoids. Some plastids had small indentations or lobes, but most were rounded or had slightly crenate edges. Numerous small granules or vesicles were present in the cells, but the lamellate granules or highly refractive bodies that are sometime found in eustigmatophycean cells were not present. The "sculpted" cell wall was comprised of ridges that form small hexagonal pits about 400 $\mathrm{nm}$ across. Reproduction was by the production of 2 or 4 autospores; no zoospores or other flagellate cells were observed. When autospores were formed, the orange body was retained without division in one of the daughter cells.

The characteristics of F4 4/24-10m are nearly identical to those of Tetraëdriella subglobosa as described by PASCHER (1930). The major feature of T. subglobosa is the presence of four ridges along the sculpted cell wall that are similar to those found on other tetrahedral coccoid algae, such as T. acuta Pascher. However, in T. subglobosa, the normally planar features of the cells are "inflated" such that the four sides of the cell are rounded. Figures 9-13 show a comparison of PASCHER's (1930) original illustrations
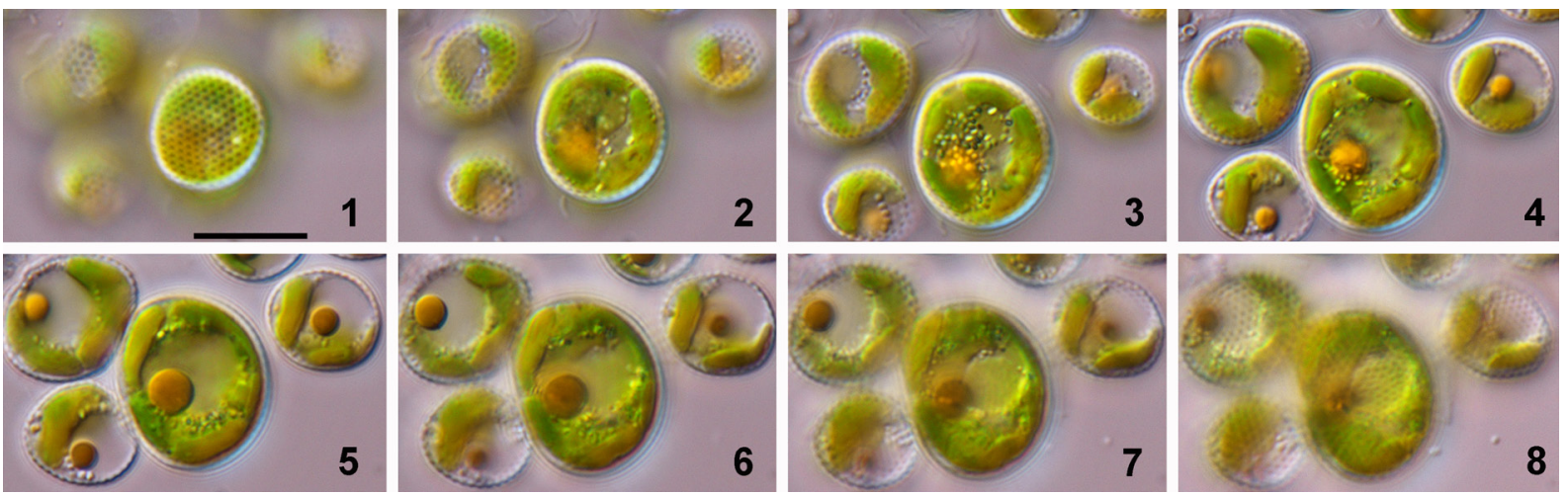

Figs 1-8. Z-stack light microscopy of vegetative cells of $T$. subglobosa: (1) shows the top surface of one cell, with the hexagonal sculpting visible; (2-7) are optical sections progressing through 4 cells that clearly show the irregular shapes of the cells and the presence of 2 plastids and the large orange lipid bodies; (8) shows the lower surface of the cells, which are also sculpted. Scale bar $10 \mu \mathrm{m}$.
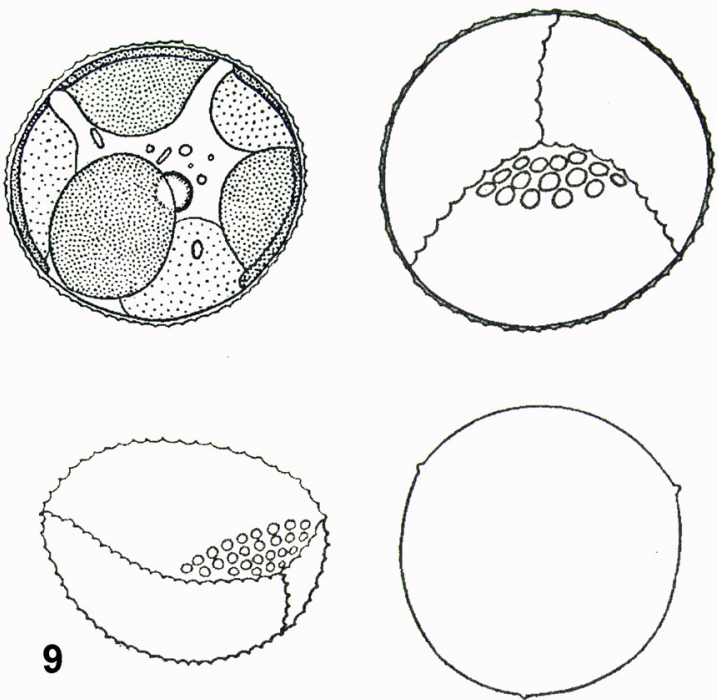
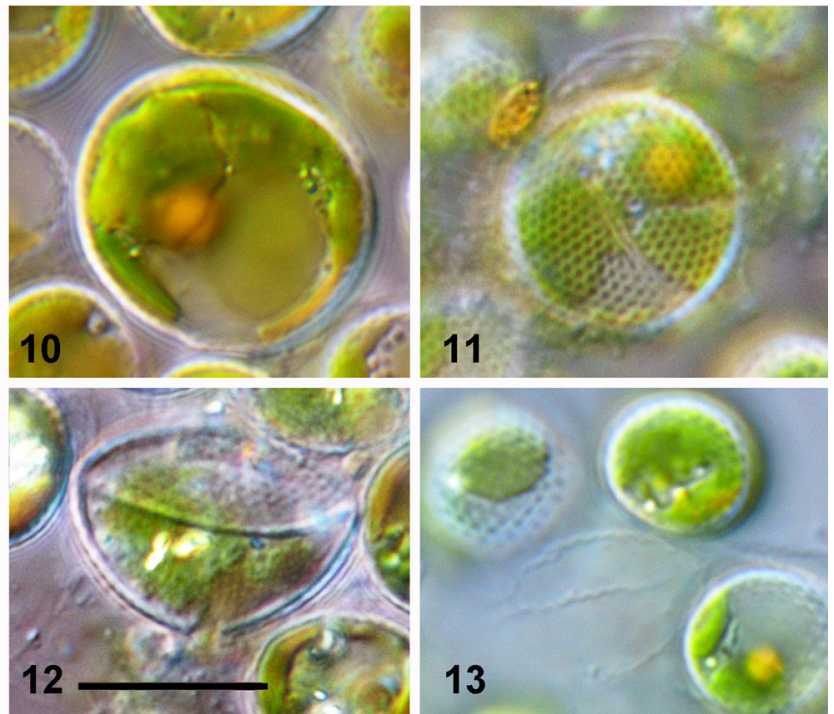

Fig. 9. Original illustrations of T. subglobosa from PASCHER (1930).

Figs 10-13. Light microscopy showing the features diagnostic for T. subglobosa as illustrated in Fig. 9: (10) internal stuctures showing the smooth-edged parietal plastids, large orange lipid body and small granular inclusions; (11) cell surface showing thickened ridge around the cell; (12) cell with flattened, nearly hemispherical shape; (13) old mother cell wall showing longitudinal ridges. Scale bar $10 \mu \mathrm{m}$. 


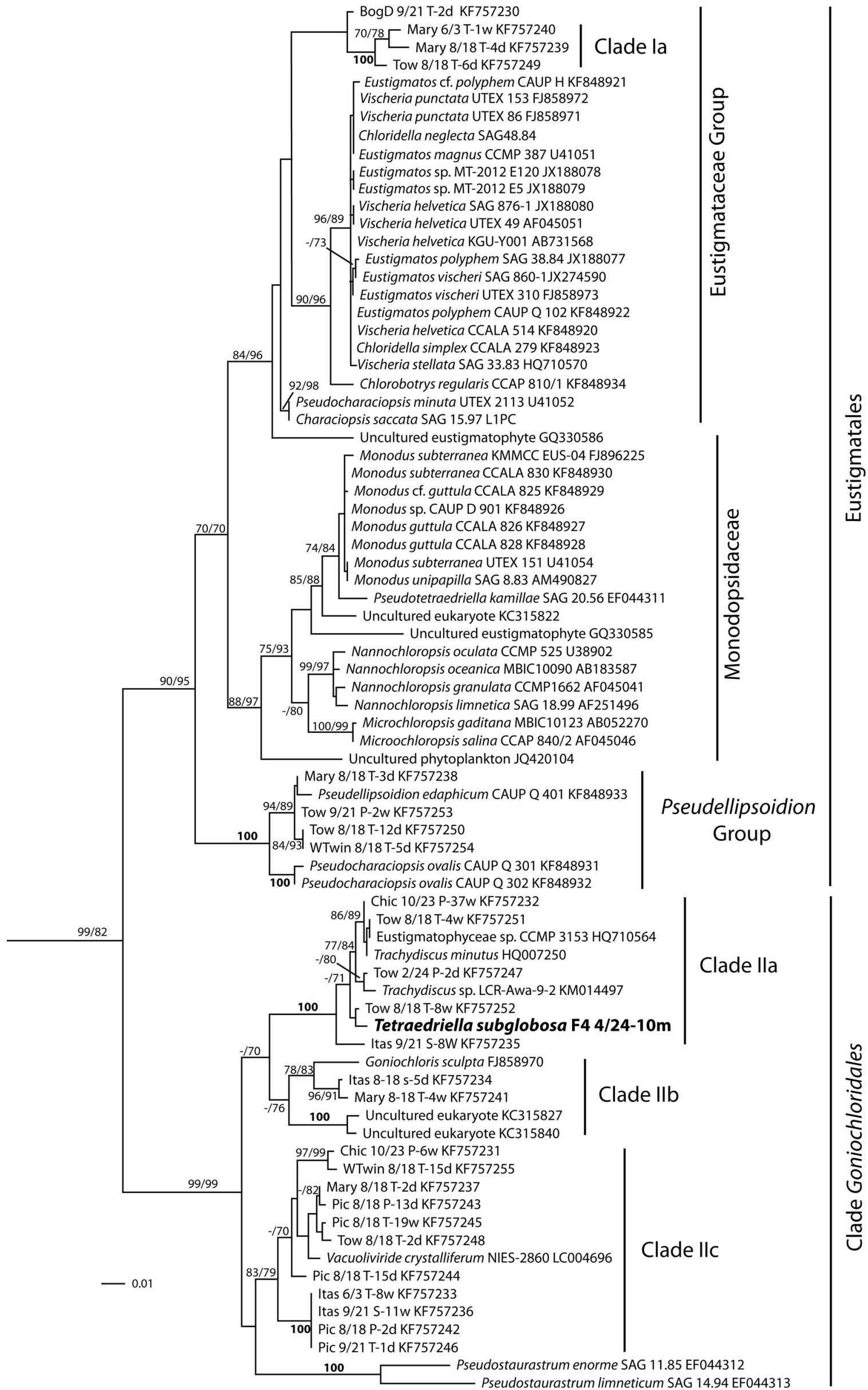




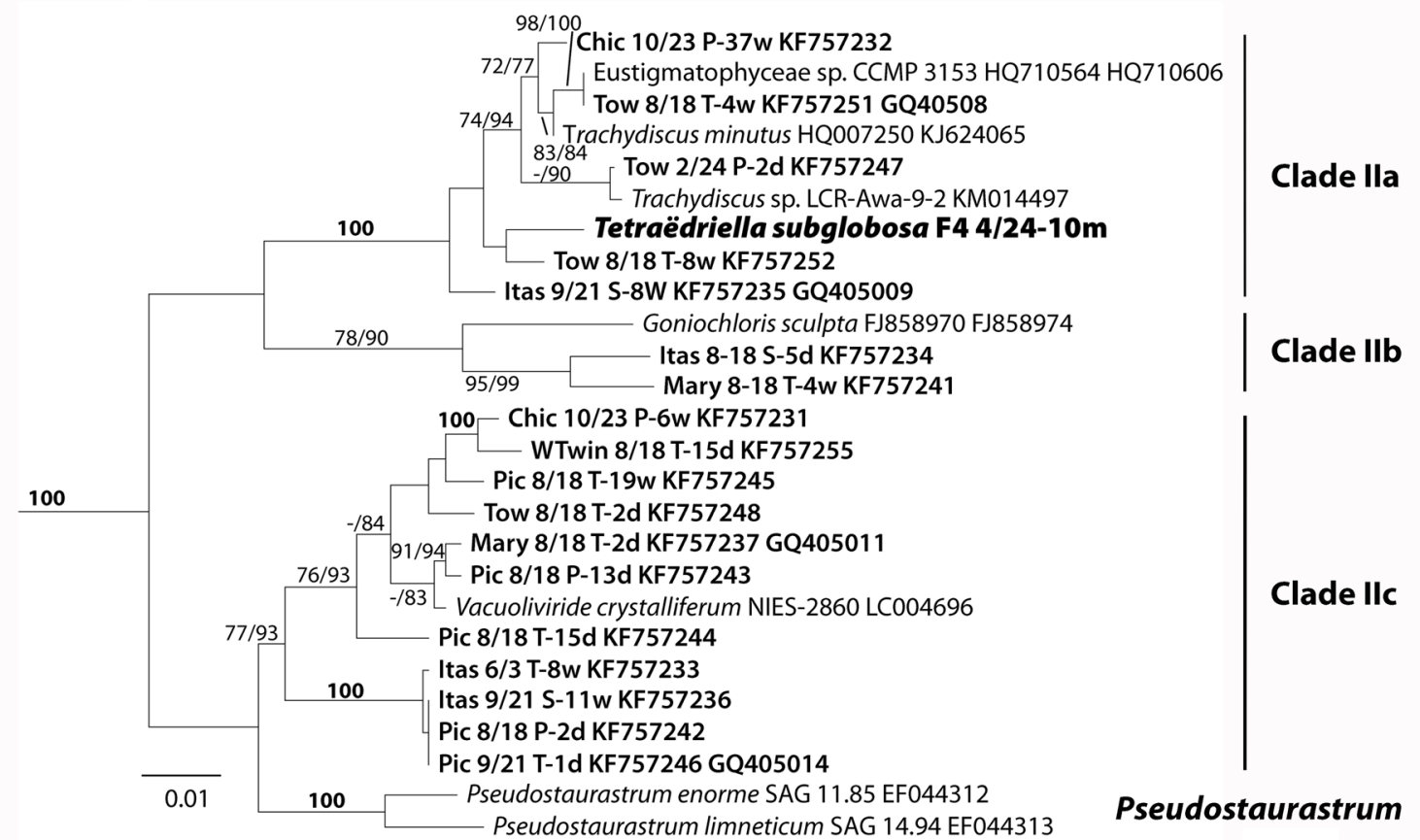

Fig. 15. Phylogenetic analysis of combined nuclear $18 \mathrm{~S}$ rDNA and plastic $r b c \mathrm{~L}$ DNA sequence data from the Eustigmatophyceae. Because of low taxon sampling for $r b c \mathrm{~L}$ sequence data from the Eustigmatales only the Goniochloridales portion of this ML phylogram is shown. New $r b c \mathrm{~L}$ data (completely new sequences or amended GenBank sequences) were generated for strains shown in bold face. Bootstrap values (70 or higher shown) are for Maximum Parsimony (1000 replicates using the fast stepwise-addition setting in PAUP*) and Maximum Likelihood (200 replicates in GARLI, with 2 random starting trees for each replicate).

Fig. 14. Phylogenetic analysis of nuclear 18S rDNA sequence data from the Eustigmatophyceae showing T. subglobosa allied with Clade IIa. The phylogram is from Maximum Likelihood analysis with the outgroup taxa not shown. Bootstrap values (70 or higher shown) are for Maximum Parsimony (1000 replicates using the fast stepwise-addition setting in PAUP*) and Maximum Likelihood (200 replicates in GARLI, with 2 random starting trees for each replicate).

of T. subglobosa (Fig. 9) and strain F4 4/24-10m (Figs 10-13). The internal morphology of the cells (Fig. 10), the presence of ridges on the cell wall (Fig. 11), the occasional cell with a flattened face (Fig. 12) and the ridges present on old mother cell walls (Fig. 13) of strain F4 4/24-10m are all identical to Pascher's drawings. In Pascher's illustration, the sculpting was shown as rounded, pore-like indentations, whereas our micrographs resolve the hexagonal sculpting. This difference is likely a result of the increased resolving power of modern microscopes with differential interference contrast.

Phylogenetic analysis of the $18 \mathrm{~S}$ rDNA sequence data (Fig. 14) confirmed the placement of strain F4 $4 / 24-10 \mathrm{~m}$ in the Eustigmatophyceae as a likely member of the unnamed lineage, Clade IIa in the clade Goniochloridales (FAwLEY et al. 2014). The results of analysis of concatenated $18 \mathrm{~S}$ and $r b c \mathrm{~L}$ sequences from a smaller set of taxa (Fig. 15) provided strong bootstrap support for this alliance, with F4 4/24-10m and the unidentified strain Tow 8/18 T-8w likely comprising a basal lineage of Clade IIa. Although the diversity and overall characteristics of Clade IIa are yet to be determined, strains from this clade all possess some type of cell wall sculpting. The only other named taxon included in Clade IIa is Trachydiscus minutus (Bourrelly)
ETTL, which has a sculpted cell wall and reproduces by autospores and zoospores. We were unable to stimulate zoospore production in Tetraëdriella subglobosa, but we have not attempted the more complex procedure used by PřIBYL et al. (2012) to stimulate zoospores in Tr. minutus. PASCHER (1930) also did not observe zoospore production for T. subglobosa.

Although T. subglobosa was one of two species originally described for the genus Tetraëdriella in the Xanthophyceae (PASCHER 1930), the other species, T. acuta Pascher, was designated the type species for the genus (KovÁČ́̌ \& KomÁreK 1976). Tetraëdriella acuta possesses cell wall sculpting and an orange lipid body (PASCHER 1930), the latter diagnostic of the Eustigmatophyceae (FAwLEY et al. 2014). In T. acuta, the cells typically possess flattened faces and appear triangular in cross-section, with ridges at the angles of the cell and slight points at each apex (PASHer 1930; EттL 1978). The genus Tetraëdriella includes several other species with the basic tetrahedral form of T. acuta and varying development of the points at cell apexes EтTL 1978): T. polychloris SkUJA, without noticeable ridges at the angles of the cells; T. impressa PASCHER and T. limbata PASCHER, with more pyramidal shapes (somewhat rounded in T. limbata) than T. acuta; and T. spinigera Skuja, with the points at the apexes extended 
forming long spine-like structures. The species $T$. jovetii (Bourelly) Bourelly and T. regularis (KüTZING) Fott have rounded arms; $T$. jovetii has no projections or ridges and $T$. regularis has short spine-like projections. Although all of the described species of Tetraëdriella are considered candidate Eustigmatophyceae (Отт et al. 2015), until the type species T. acuta can be isolated and evaluated, we can only speculate that the genus Tetraëdriella should be transferred from the Xanthophyceae to the Eustigmatophyceae. Even if T. acuta and other species of the genus were to be shown to be in the Eustigmatophyceae they may not be allied with $T$. subglobosa. There is a report of unpublished $18 \mathrm{~S}$ rDNA sequence data that place two species of Tetraëdriella in the Eustigmatophyceae (Отт et al. 2015) and those results should help clarify these issues. Several species of Tetraëdriella have an orange lipid body (ETTL 1978) similar to those found in the Eustigmatophyceae, but until these species are isolated and characterized the relationships among these species are open to question.

Tetraëdriella subglobosa might be considered rare based on the paucity of sightings. However, this species and other species of the Eustigmatophyceae are probably frequently overlooked. Most Eustigmatophyceae are spherical or nearly so and quite small, often less than $10 \mu \mathrm{m}$ in diameter. The yellow, orange or red lipid body is a simple way to recognize Eustigmatophyceae (FAwLEY et al. 2014), but it can be difficult to see without very good optics. As phycologists become more aware of this interesting and diverse class of algae, it is likely that they will be found more frequently.

\section{ACKNOWLedgements}

This work was supported by the National Science Foundation (grant number DEB1145414), the Arkansas INBRE program through a grant (P20 GM103429) from the National Institute of General Medical Sciences of the National Institutes of Health, the Arkansas Space Grant Consortium and a University of Arkansas at Monticello Faculty Research Grant. We thank Nathan Probst and Sara Prior for technical assistance. We thank one anonymous reviewer for a very careful review of the manuscript and helpful comments. Special thanks to Pavel Škaloud and Jan Št'astný of the Phycology Research Group in Prague for hosting our wonderful expedition to "the swamp" at Lake Mácha.

\section{REFERENCES}

EtTl, H. (1978): Xanthophyceae 1. - In: Ettr, H.; GerLofF, J. \& Heynig, H. (eds): Süßwasserflora von Mitteleuropa, Band 3. - 530 pp., Gustav Fischer Verlag, Stuttgart - Jena.

Fawley, K. P.; Elíšs, M. \& Fawley, M. W. (2014): The diversity and phylogeny of the commercially important algal class Eustigmatophyceae, including the new clade Goniochloridales. - Journal of Applied Phycology 26: 1773-1782.

Fawley, M. W. \& Fawley, K. P. (2004): A simple and rapid technique for the isolation of DNA from microalgae. - Journal of Phycology 40: 223-225.

Fawley, M.W.; Fawley, K.P. \& Buchheim, M.A. (2004):
Molecular diversity among communities of freshwater microchlorophytes. - Microbial Ecology 48: 489-499.

Fawley, M.W.; Fawley, K.P. \& Hegewald, E. (2013): Desmodesmus baconii (Chlorophyta) a new species with double rows of arcuate spines. - Phycologia 52: $565-572$.

Fawley, M. W.; Jameson, I. \& Fawley, K. P. (2015): The phylogeny of the genus Nannochloropsis (Monodopsidaceae, Eustigmatophyceae), with descriptions of $N$. australis sp. nov. and Microchloropsis gen. nov. - Phycologia 54: 545-552.

Guiry, M. D. \& Guiry, G. M. (2015): AlgaeBase. Worldwide electronic publication, National University of Ireland, Galway. - http://www.algaebase.org; searched on 12 November 2015.

KovÁČIK, L. \& KoMÁreK, J. (1976): Proposal to conserve the genus names Tetraedron Kützing ex Koršikov (1953) and Tetraedriella Pascher (1930). - Taxon 25:201203.

Lee, K. W. \& Bold H. C. (1973): Pseudocharaciopsis texensis gen. et sp. nov., a new member of the Eustigmatophyceae. - British Phycological Journal 8: 31-7.

Maddison, D. R. \& Maddison, W. P. (2000): MacClade 4: analysis of phylogeny and character evolution. Sinauer Associates, Sunderland Massachusetts.

Otт, D. W.; Oldham-Ott, C. K.; Rybalka, N. \& Friedl, T. (2015): Xanthophyte, Eustigmatophyte, and Raphidophyte Algae. - In: Wehr, J. D.; Sheath, R. G. \& Kociolek, J.P. (eds): Freshwater Algae of North America: Ecology and Classification, 2nd edition. pp. 483-534, Academic Press, San Diego.

PAscher, A. (1930): Zur Kenntnis der heterokonten Algen. Archiv für Protistenkunde 69: 401-451.

PoulíčKovÁ, A.; LhotskÝ, O. \& DŘímalová, D. (2004): Prodromus sinic a řas České Republiky. - Czech Phycology 4: 19-33.

Přıbyl, P.; Eliáš, M.; Cepák, V.; LuKavskÝ, J. \& KašTÁneK, P. (2012): Zoosporogenesis, morphology, ultrastructure, pigment composition, and phylogenetic position of Trachydiscus minutus (Eustigmatophyceae, Heterokontophyta). - Journal of Phycology 48: 231242.

Prior, S. E.; Fawley, M. W. \& Fawley, K. P. (2009): DNA sequence analysis of freshwater Eustigmatophyceae, a potential source of essential fatty acids. - Journal of the Arkansas Academy of Science 63: 139-144.

Santos, L. M. A. \& Leedale, G. F. (1991): Vischeria stellata (Eustigmatophyceae): ultrastructure of the zoospores, with special reference to the flagellar apparatus. - Protoplasma 164: 160-167.

Swofford , D. L. (2002): PAUP*: Phylogenetic Analysis Using Parsimony (*and Other Methods), version 4.0 beta. - Sinauer Publishing, Sunderland MA, USA.

TAVARÉ, S. (1986): Some probabilistic and statistical problems in the analysis of DNA sequences. - In: MiURA R. M. (ed.): Some Mathematical Questions in Biology_-DNA Sequence Analysis. - pp. 57-86, American Mathematical Society, Providence.

Trzcińska, M.; Pawlik-Skowrońska, B.; Krokowski, D. \& Watanabe, S. (2014): Genetic and morphological characteristics of two ecotypes of Eustigmatos calaminaris sp. nov. (Eustigmatophyceae) inhabiting $\mathrm{Zn}$ - and $\mathrm{Pb}$-loaded calamine mine spoils. - Fottea 14: $1-13$. 
ZwICKL, D. J. (2006): Genetic Algorithm Approaches for the Phylogenetic Analysis of Large Biological Sequence Datasets under the Maximum Likelihood Criterion. Dissertation, the University of Texas at Austin, Austin, Texas, USA.

(C) Czech Phycological Society (2016)

Received May 31, 2016

Accepted June 28, 2016 